\title{
EVALUATATING THE APPLICATION OF SURFACE AND SUB-SURFACE TRICKLE IRRIGATION SYSTEMS FOR PLANTING ACTIVE PEAS IN SANDY SOIL
}

\author{
Abou El Azem', A. M., Nessrien S. Abdel Kareem ${ }^{2}$ \\ and M. A. M. Moursy ${ }^{2}$
}

ABSTRACT

The current study investigates two modern irrigation systems, (i.e. surface and sub-surface trickle irrigation systems). It was applied in Wadi ElNatron Experimental Station, which represents the new lands condition and it was applied on active pea crop. Three different emitter's discharges equal to 2, 4 and $8 \mathrm{l} / \mathrm{h}$ and two irrigation systems were evaluated based on six indicators, (i.e. yield, water application, water consumption, water use efficiency, soil moisture and salt patterns). Both investigated systems were tested under two conditions (i.e. $100 \%$ and $50 \%$ of the net crop water requirements).

The results indicated a privilege for using sub-surface trickle irrigation system (i.e. according to the different indicators). The sub-surface trickle irrigation system had higher yield, higher Water Use Efficiency, lower water application and water consumption compared to surface trickle irrigation when $100 \%$ of the net crop water requirements and $4 \mathrm{l} / \mathrm{h}$ emitter discharge were used. Also, this system gave sufficient available water and best distribution of moisture in the root zone. It was thus recommended to use the above conditions, under sandy soil, to achieve the lowest water application, water consumption, highest crop yield and water use efficiency.

Keywords: trickle irrigation, yield, water use efficiency, water consumption

\section{INTRODUCTION}

$\Omega$ rickle irrigation is very important for optimum management of water in arid and semi-arid regions. Water is lost by runoff in heavy lands with low infiltration rate and by deep percolation in sandy soils if traditional irrigation systems are used. Trickle irrigation system has aroused considerable interest for land, water use, crop growth and productivity. It is widely regarded as modern irrigation system which increases production and decreases water consumption.

\section{Prof. Water management research institute, NWRC \\ 2 Researcher. Water management research institute, NWRC}


El Berry et al. (1990) found that the use of surface and subsurface trickle irrigation provided great potentials for vegetable production in arid areas. In addition to higher expected yield, it reduced crop management costs and water demands. Martinez et al. (1991) concluded that nutrients uptake by plant is greater in subsurface than surface trickle. Shallevet (1994) concluded that the effects of soil salinity and water stress are generally added in their impacts on crop evapotranspiration. Therefore, the same yield-ET functions may hold for both water shortage induced stress and for salinity induced stress. Abou El Azem et al. (2002) found that the subsurface trickle had significantly favored vegetable fresh yield compared to surface irrigation. Both of them exhibited sufficient available water in the top soil layers of $(0-30 \mathrm{~cm})$ where the plants consumed most of their water demand. The soil salinity increased vertically from the line source or the emitter till it reached maximum values at the soil surface just above the line in the subsurface and at the mid layer beneath the emitter in the surface irrigation and at the bottom of the wetted zone in both systems. Moreover, the soil salinity was increased by increasing the irrigation water levels, while it was decreased by decreasing the fertilizers levels under both of them. Assouline (2002) found that the wetting patterns during application generally consist of two zones i.e. a saturated zone close to the emitters and a zone where the water content decreases towards the wetting front. Increasing the discharge rate generally results in an increase in the wetted soil diameter and a decrease in the wetted depth.

Therefore; this study was set in order to study the effect of different emitters discharge rates $(2,4$ and $8 \mathrm{l} / \mathrm{h})$ and two irrigation water levels (i.e. 100 and $50 \%$ of calculated amounts using A pan method) on water application, water consumption, active pea yield, water use efficiency, moisture and salt distributions under two trickle irrigation systems (i.e. surface and subsurface systems) at West Delta region.

\section{MATERIALS AND METHODS}

A field experiment was carried out during winter season of 2010/2011 in the Water Management Research Station at Wadi El Natron, El Behera Governorate.

The soil physical and chemical properties of the experimental plots were determined according to [Klute, 1986 and Page, et al. 1982 ], table (1). 
The irrigation water was obtained from local well and was analyzed chemically, table (1).

Table (1) Physical characteristics so as chemical properties of soil and chemical analysis of irrigation water

\begin{tabular}{|c|c|c|c|c|c|c|c|c|}
\hline$\underbrace{\text { Depth }(\mathrm{cm})}_{\text {Property }}$ & है & 宇 & $\begin{array}{l}\text { ô } \\
\text { ò } \\
\text { f }\end{array}$ & Property & ఏ્ત & ồ & $\begin{array}{l}\text { ô } \\
\text { o } \\
\text { f }\end{array}$ & $\begin{array}{c}\text { Irrigation } \\
\text { water }\end{array}$ \\
\hline \multirow{11}{*}{$\begin{array}{l}\text { Sand }(\%) \\
\text { Silt }(\%) \\
\text { Clay }(\%) \\
\text { Texture } \\
\text { Field capacity by weight }(\%) \\
\text { Permanent wilting point by } \\
\text { weight }(\%) \\
\text { Available water }(\%) \\
\text { Bulk density }\left(\mathrm{gm} / \mathrm{cm}^{3}\right)\end{array}$} & 94.5 & 95.0 & 95.7 & $\mathrm{ph}$ & 8.23 & 8.11 & 7.97 & 7.14 \\
\hline & 3.5 & 3.3 & 3.0 & $\mathrm{EC}(\mathrm{dS} / \mathrm{m})$ & 1.46 & 1.56 & 1.63 & 1.18 \\
\hline & 2.0 & 1.7 & 1.3 & $\mathrm{CO}_{3}=-$ & 0.1 & 0.1 & 0.1 & 0.1 \\
\hline & \multicolumn{3}{|c|}{ Sandy } & $\mathrm{HCO}_{3}^{-}$ & 0.93 & 1.15 & 1.33 & 4.7 \\
\hline & 8.03 & 913 & 1007 & $\mathrm{CL}^{-}$ & 1.98 & 2.05 & 3.11 & 10.6 \\
\hline & 3.33 & 3.14 & 2.99 & $\mathrm{SO}_{4}=$ & 9.61 & 9.85 & 10.16 & 8.15 \\
\hline & 5.53 & 5.14 & 2.99 & $\mathrm{Ca}^{++}$ & 6.23 & 6.45 & 6.65 & 1.8 \\
\hline & 4.7 & 5.99 & 7.08 & $\mathrm{Mg}^{++}$ & 2.24 & 2.26 & 2.29 & 2.8 \\
\hline & 1.65 & 1.56 & 1.44 & $\mathrm{Na}^{+}$ & 3.44 & 3.76 & 3.91 & 18.4 \\
\hline & & & & $\mathrm{K}^{+}$ & 0.51 & 0.58 & 0.65 & 0.55 \\
\hline & & & & SAR & 1.66 & 1.74 & 1.84 & 12.2 \\
\hline
\end{tabular}

\section{a. The irrigation systems}

Two irrigation systems were installed in the experimental area. Both surface and subsurface trickle irrigation systems consisted of control head (centrifugal pump, pressure regulator, pressure gauges, flow meter and filters), PVC main, sub-main, and secondary lines. PVC pipes diameters (i.e. 150, 110 and $63 \mathrm{~mm}$ ) were used for main, sub-main and secondary lines, respectively. Laterals trickle GR lines made of polyethylene pipes with $16 \mathrm{~mm}$ diameters, $30 \mathrm{~cm}$ emitters distance and 2, 4, 8 1/h emitter's discharges were used for both trickle irrigation systems. The type of emitters of both studied systems was GR which was either placed on soil surface or buried approximately $15 \mathrm{~cm}$ deep directly under the soil beds. The sub main line was equipped with a valve, a water meter and a pressure gauge. The lengths of laterals and spacing between them were 10 and $0.75 \mathrm{~m}$, for both systems, figure (1).

\section{b. The cultivated crop}

Active pea (Pisum sativum L.) plants c.v. Little Marvel uptake was sown at the rate of 2 seeds/hill and hand planted at $3-5 \mathrm{~cm}$ depth on $30 \mathrm{~cm}$ planting space and $60 \mathrm{~cm}$ between rows on 25/10/2010. Harvesting took place on the 28th of January, 2012 each 5 to 6 days till approximately the 
end of June. Superphosphate at rate of $300 \mathrm{Kg} / \mathrm{fed}\left(15.5 \% \quad \boldsymbol{P}_{2} \boldsymbol{O}_{5}\right)$, potassium sulfate at rate of $50 \mathrm{Kg} / \mathrm{fed}\left(48 \% \boldsymbol{K}_{2} \mathrm{O}\right)$ and ammonium sulfate at rate of $100 \mathrm{Kg} / \mathrm{fed}(20.5 \% \mathrm{~N})$ were used. One third of these amounts were added at soil preparation and the other two thirds were divided into eight equal portions and added weekly.

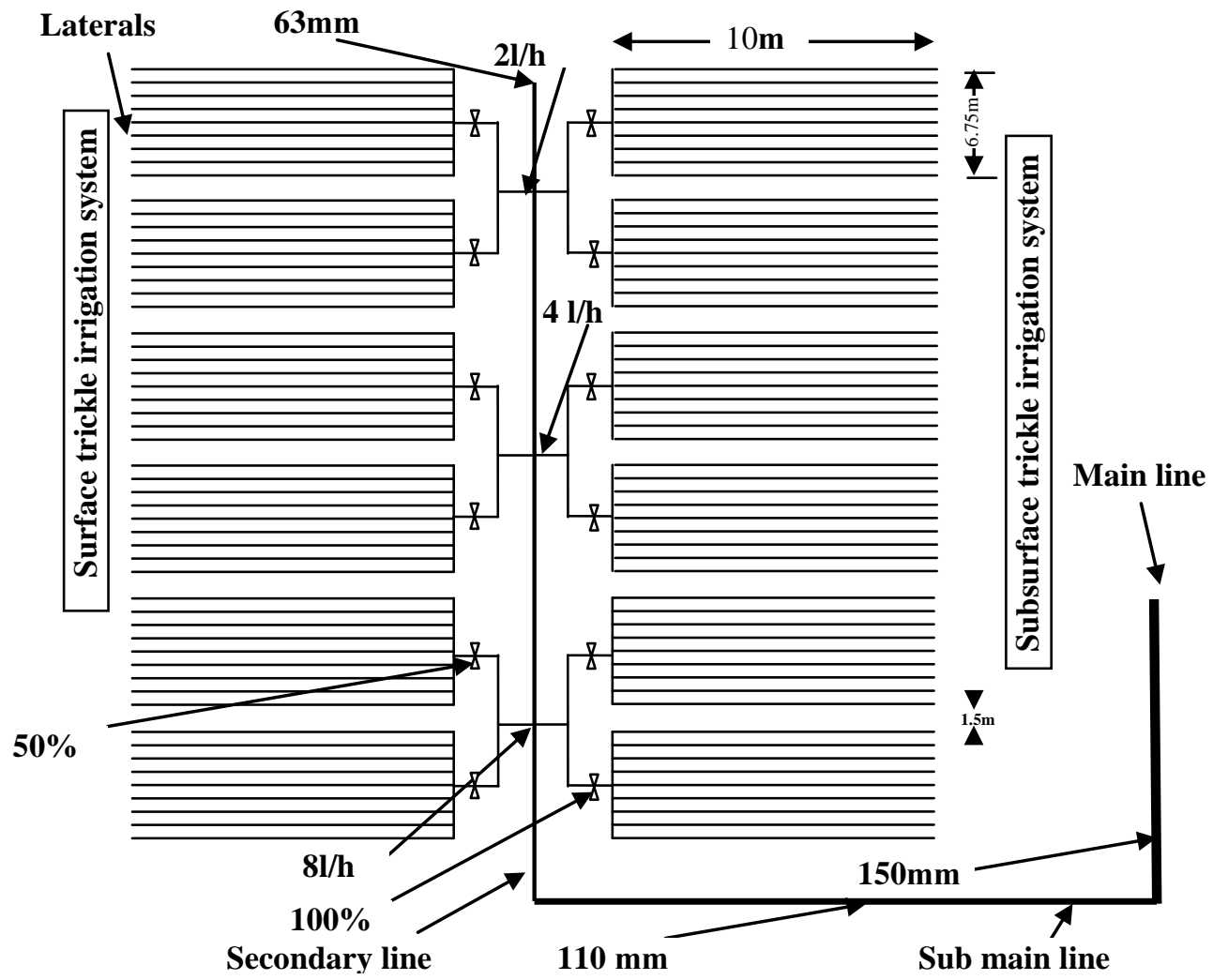

Figure (1) Layout of experimental plots under the studied treatment

\section{c. Exerimental design}

The effect of different emitters discharge rates (i.e. 2, 4 and $81 / \mathrm{h}$ ), and two irrigation water levels (i.e. 100 and $50 \%$ of calculated amounts using class A pan method) on moisture and salt distribution was investigated, experimentally.

The experiment included twelve treatments which were the combination between two irrigation systems (i.e. surface and subsurface trickle irrigation systems), three emitters discharge rates (i.e. 2,4 and $81 / \mathrm{h}$ ) and two irrigation water levels (i.e. 100 and $50 \%$ of calculated amounts using class A pan method). 
These treatments were arranged in a split-split plot design with four replicates. Irrigation water levels were in the main plots, emitters discharge rates were distributed in the sub plots and irrigation systems were randomly distributed in the sub - sub plots. Plot area was $67.5 \mathrm{~m}^{2}$. It contains 9 emitter lines with $10 \mathrm{~m}$ length and $75 \mathrm{~cm}$ distance. The distance between emitters was $30 \mathrm{~cm}$. 1.5 meters were left between each two irrigation treatments as a guard distance to avoid the interactions of irrigation water.

\section{d. Measurements and calculations}

Evaluation of the above mentioned experimental parameters was carried out taking into consideration the following indicators:

\section{Water relation}

The irrigation water requirements were calculated according to the following equation, Vermeiren and Jobling (1980)

$$
I R c=\frac{\left\lfloor\left(E T_{0} \times K c\right) \times D d\right\rfloor+L f}{E s}
$$

Where:

$I R c=$ irrigation water requirements, $\mathrm{mm} /$ intervals. $\mathrm{Lf}=$ Leaching fraction. $E T_{o}=$ evapotranspiration, $\mathrm{mm} / \mathrm{day} . \quad E s=$ system efficiency, \%. $k c=$ crop coefficient for (Doorenbos and Kassam,1979). $\quad D d=$ time intervals

Evapotranspiration was calculated by using the pan coefficient calculated according to Doorenbos and Pruitt (1977) as follow:

$$
\text { ETo }=\text { Kp } x \text { Epan }
$$

Where:

$\boldsymbol{K} \boldsymbol{p}$ : Coefficient of pan Epan: Evaporation of pan, $\mathrm{mm} / \mathrm{day}$.

Leaching factor under irrigation systems was calculated according to the following equation:

$$
L f=\frac{E C w}{2 \max E c e}
$$

Where:

$E C w=$ salinity of the applied irrigation water, $\mathrm{dS} / \mathrm{m}$.

$E C e=$ average soil salinity tolerated by the crop as measured on a soil saturation extract, $\mathrm{dS} / \mathrm{m}$. 
The quantities of water consumptive use were calculated using the following equation as described by Israelsen and Hansen (1962).

$$
W_{c u}=\frac{\theta_{2}-\theta_{1}}{100} \times B d \times d
$$

Where:

$W_{c u}=$ water consumptive use, $\mathrm{mm}$.

$\theta_{1}=$ soil moisture content before irrigation by weight, $\%$.

$\theta_{2}=$ soil moisture content after irrigation by weigh, $\%$.

$B d=$ bulk density, $\mathrm{gm} / \mathrm{cm}^{3} \quad d=$ soil depth, $\mathrm{mm}$.

The mean values of the meteorological data for pea growing season at Wadi El Natron area are presented in table (2).

Table (2) The mean values of meteorological data for the study area

\begin{tabular}{|c|c|c|c|c|c|c|}
\hline \multirow[t]{2}{*}{ Month } & \multicolumn{2}{|c|}{$\begin{array}{c}\text { Temperature } \\
\left({ }^{\circ} \mathrm{c}\right)\end{array}$} & \multirow{2}{*}{$\begin{array}{l}\text { Wind } \\
\text { speed } \\
(\mathrm{m} / \mathbf{s})\end{array}$} & \multirow{2}{*}{$\begin{array}{c}\text { Relative } \\
\text { humidity } \\
(\%)\end{array}$} & \multirow{2}{*}{$\begin{array}{c}\text { ET0 } \\
(\mathbf{m m} / \text { day })\end{array}$} & \multirow{2}{*}{$\begin{array}{r}\text { Rain fall } \\
(\mathbf{m m} / \text { day })\end{array}$} \\
\hline & Max. & Min. & & & & \\
\hline Oct. & 27.3 & 16.0 & 0.85 & 85.5 & 3.40 & 0.3 \\
\hline Nov. & 22.7 & 14.5 & 0.80 & 86.3 & 2.55 & 0.9 \\
\hline Dec. & 18.9 & 9.3 & 0.55 & 89.5 & 1.85 & 2.0 \\
\hline Jan. & 18.3 & 7.9 & 0.50 & 68.9 & 1.75 & 4.0 \\
\hline Feb. & 19.4 & 9.7 & 0.55 & 70.1 & 2.05 & 1.5 \\
\hline Mar. & 21.8 & 10.1 & 0.60 & 80.5 & 3.45 & 1.0 \\
\hline
\end{tabular}

\section{Plant characteristics}

Number of plants $/ \mathrm{m}^{2}$, stem length $(\mathrm{cm})$, counts the number of pods/plant and pods weight (gm)/plant and total yield of green pods.

\section{Water use efficiencies}

These were calculated according to Jensen (1983) as follows:

$$
\begin{aligned}
& \text { WUE }_{\text {crop }}=\frac{\text { Fresh yield }(\mathrm{kg} / \mathrm{fed})}{\text { Actual consumptive use }\left(\mathrm{m}^{3} / \mathrm{fed}\right)}, \mathrm{kg} / \mathrm{m}^{3} \\
& \mathrm{WUE}_{\text {field }}=\frac{\text { Fresh yield }(\mathrm{kg} / \mathrm{fed})}{\text { Amount of water applied }\left(\mathrm{m}^{3} / \mathrm{fed}\right)}, \mathrm{kg} / \mathrm{m}^{3}
\end{aligned}
$$

\section{Moisture and salt distribution:}

Soil samples were taken 48 hours after the irrigation to determine the normal distribution pattern of moisture and salt in the soil. These samples were taken to represent the different depths of (0-15), (15-30), (30-45) and (45-60) $\mathrm{cm}$ and at each distance of $0,10,20,30,40,50$ and $60 \mathrm{~cm}$ from both emitters lines sides. $30 \mathrm{~cm}$ distance was just beside the emitter. 
Moisture content in the soil sample was determined gravimetrically and calculated on dry basis according to Garcia (1978).

\section{e. Statistical analysis}

The obtained data were subjected to statistical analysis of variance. Values of $\boldsymbol{L}$.S.D. were obtained whenever the calculated " $\boldsymbol{F}$ " values were significant at 5\% and 1\% levels, Snedecor and Cochran (1980).

\section{RESULTS AND DISCUSSION}

The results were analyzed and presented graphically. From these graphs and results, the following was observed.

Regarding the results of irrigation water requirements and water consumptive use of pea plants from sowing to harvesting for the different studied treatments, they are presented in figure (2).The results showed that for each irrigation level (100 and 50\%) and each emitter discharge (2, 4 and $81 / \mathrm{h}$ ) treatment under both surface and subsurface trickle irrigation systems the irrigation water requirement were $\{(459.4$ and 229.7), (462.2 and 231.1) and (467.3 and 273.7) $\}$ and \{(445.8 and 217.9), (451.2 and 227.6) and (454.4 and 267.2) cm, respectively. Moreover, the treatments irrigated with $100 \%$ received the highest irrigation water requirement under both trickle systems. On the other hand, the treatments irrigated with $21 / \mathrm{h}$ emitters discharges utilized the lowest irrigation water requirement. It is also clear from the results that the values of water consumptive use increased with increasing the irrigation levels especially with using $4 \mathrm{l} / \mathrm{h}$ emitters discharge as well as the other two discharges under both trickle systems.

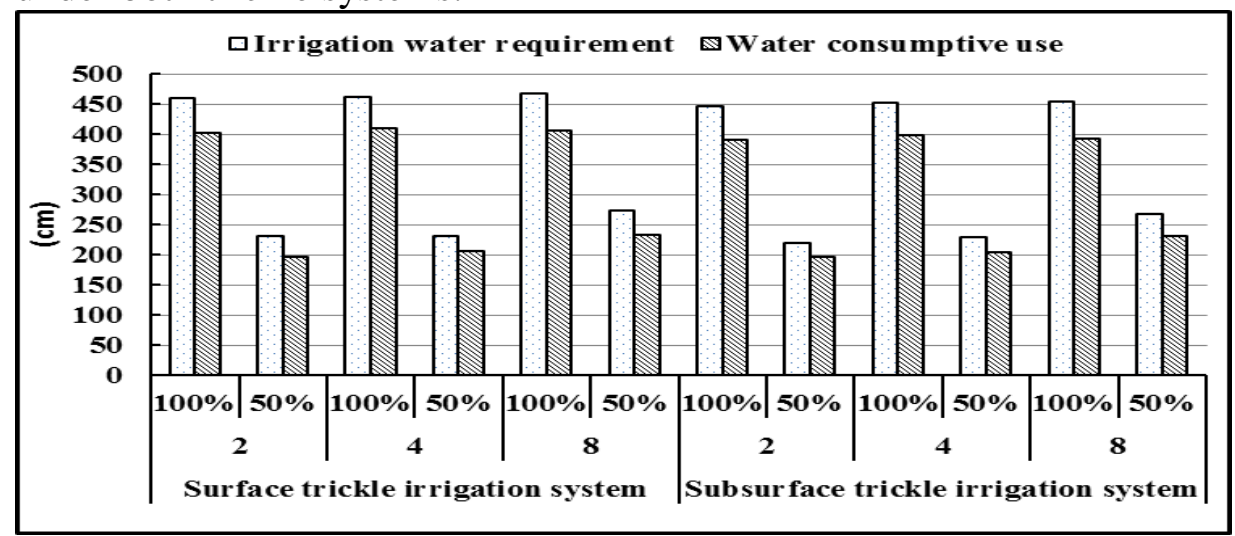

Figure (2) Irrigation water requirements and water consumptive use under different treatment. 
These results could be due to the increase of plant growth which increased total leaf area. The transpiration increased, consequently water consumption increased. The water consumptive use values of pea plants were \{(401.2 and 196.1), (409.0 and 205.5) and (406.1 and 232.6)\} and (390.5 and 195.3), (397.2 and 202.6) and (392.9 and 230.4) cm, for irrigation levels (100 and 50\%) and emitter discharges (2, 4 and 81/h) treatment under both surface and subsurface trickle irrigation systems, respectively.

As for the results of the Plant Growth, they are listed in table (3). The table holds the number of plants $/ \mathrm{m}^{2}$, stem length $(\mathrm{cm})$, number of pods/plant its weight (gm/plant) as affected by studied treatments. The results indicated that all the characteristics were significantly increased with all the studied treatments under subsurface trickle irrigation system than under surface one. The results showed that, the lowest irrigation water levels treatment with each emitter discharge decreased all characteristics of them than the highest irrigation levels treatment with the same discharge under it. Low irrigation water and discharge rates reduced all characteristics under both systems. Obtained results are in accordance with those reported by El Mansi et. al., (1999) and Abou El Azem et. al., (2002).

Pea fresh yield as affected by irrigation systems, emitters discharge rates and irrigation water levels are presented in table (3) and figure (3). The results revealed that fresh yield of pea were significantly affected by all the studied treatments. The highest fresh yield was obtained by using subsurface followed by surface trickle irrigation system treatments irrigated with the highest irrigation level and 41/h emitter discharge (1990 and $1650 \mathrm{Kg} / \mathrm{fed}$ ) compared to surface trickle treatments irrigated by both irrigation levels with each emitter discharge and subsurface treatments irrigated by both irrigation levels with 2 and 81/h emitter discharges. In the meantime the subsurface trickle treatments irrigated with both irrigation levels and each emitter discharge fresh yield were significantly higher than that obtained from all the same studied treatments under surface trickling. On the contrary, the lowest fresh yield were obtained for surface trickle irrigation system treatment irrigated with the lowest irrigation level and $2 \mathrm{l} / \mathrm{h}$ emitter discharge $(350 \mathrm{Kg} / \mathrm{fed})$ compared to all the 
studied treatments. Concerning irrigation water levels, it is obvious that decreasing irrigation levels at $50 \%$ decreased the fresh yield by 56.25 , $54.55,44.44,56.71,50.40$ and $42.68 \%$ under using 2,4 and $81 / \mathrm{h}$ emitters discharges under both surface and subsurface trickle systems, respectively than treatments received irrigation level $100 \%$ with the same emitters discharges under the same trickle system. These results could be assigned to the sensitivity of the crop to over irrigation which controlled by the limits under study.

Table (3) Plant characters, total fresh yield and water use efficiencies of crop and field of pea plants as affected by studied treatments.

\begin{tabular}{|c|c|c|c|c|c|c|c|c|c|c|c|c|}
\hline $\begin{array}{c}\text { Irrigation } \\
\text { svstem }\end{array}$ & \multicolumn{6}{|c|}{ Surface trickle irrigation } & \multicolumn{6}{|c|}{ Sub surface trickle irrigation } \\
\hline $\begin{array}{c}\text { Emitter } \\
\text { discharge }\end{array}$ & \multicolumn{2}{|c|}{$2 \mathrm{l} / \mathrm{h}$} & \multicolumn{2}{|c|}{$4 \mathrm{l} / \mathrm{h}$} & \multicolumn{2}{|c|}{$8 \mathrm{l} / \mathrm{h}$} & \multicolumn{2}{|c|}{$2 \mathrm{l} / \mathrm{h}$} & \multicolumn{2}{|c|}{$4 \mathrm{l} / \mathrm{h}$} & \multicolumn{2}{|c|}{$8 \mathrm{l} / \mathrm{h}$} \\
\hline $\begin{array}{c}\text { Irrigation } \\
\text { level }\end{array}$ & $100 \%$ & $50 \%$ & $100 \%$ & $50 \%$ & $100 \%$ & $50 \%$ & $100 \%$ & $50 \%$ & $100 \%$ & $50 \%$ & $100 \%$ & $50 \%$ \\
\hline $\begin{array}{c}\text { No. of } \\
\text { plants } / \mathbf{m}^{2}\end{array}$ & 7 & 5 & 11 & 9 & 8 & 6 & 10 & 8 & 14 & 10 & 12 & 9 \\
\hline $\begin{array}{l}\text { Stem } \\
\text { length } \\
\text { (cm) }\end{array}$ & 35 & 28 & 55 & 39 & 43 & 30 & 43 & 36 & 59 & 44 & 51 & 38 \\
\hline $\begin{array}{c}\text { No. of } \\
\text { pods/plant }\end{array}$ & 82 & 50 & 140 & 85 & 100 & 78 & 100 & 60 & 160 & 94 & 133 & 80 \\
\hline $\begin{array}{l}\text { Weight of } \\
\text { pods } \\
(\mathrm{gm}) / \mathrm{plant}\end{array}$ & 191.9 & 108.7 & 439.2 & 178.2 & 320.9 & 158.5 & 299.9 & 181.3 & 550.4 & 198.5 & 385.1 & 288.2 \\
\hline
\end{tabular}

L.S.D. of irrigation system (a) at 0.05

L.S.D. of emitters discharge (b) at 0.05

L.S.D. of irrigation water levels (c) at 0.05

L.S.D. of $\mathrm{a} \times \mathrm{b}$ at 0.05

L.S.D. of a $x$ c at 0.05

L.S.D. of $b \times c$ at 0.05

L.S.D. of a $\mathrm{x} b \mathrm{x} \mathrm{c}$ at 0.05
15.24

18.58

20.11

24.62

28.22

30.62

47.21

Concerning the interaction effect between irrigation systems, irrigation levels and emitters discharges on fresh yield, it was noticed that the interaction had significant effect. The best combination of all these treatments was irrigated the pea plants using the irrigation level $100 \%$ of calculated amounts using class A pan with $41 / \mathrm{h}$ emitters discharge under subsurface trickle system.

Concerning the results of water use efficiency, they are presented in figure (4). They were affected by emitter discharges and irrigation water levels under surface and subsurface trickle irrigation systems. The results 
revealed that both crop and field water use efficiencies were increased significantly by $18.97,19.33,33.68,19.61,19.05,32.93,16.00,25.00$, $34.41,20.00,25.24$ and $35.00 \%$ when the irrigation water levels were 100 and 50\% under subsurface trickle system compared with the same levels under surface system, respectively. In the meantime, both crop and field water use efficiencies were directly related to both the irrigation water and emitter discharge levels (within the tested levels).This relation revealed that both crop and field water use efficiencies increased linearly with increasing both irrigation water and discharge levels. Obtained results are in accordance with those reported by Abou El Azem and Abdel Aal (2009). Concerning the interaction impact of irrigation water applied levels and emitter discharge levels on crop and field water use efficiencies, the results indicated that the highest crop and field water use efficiencies values were obtained when the pea plants irrigated by $100 \%$ irrigation level and 41/h emitter discharge under both subsurface and surface trickle irrigation systems $\left(1.19,1.05,0.96\right.$ and $0.85 \mathrm{~kg} / \mathrm{m}^{3}$, respectively). However, the lowest values of them $(0.42,0.36,0.47$ and $0.41 \mathrm{~kg} / \mathrm{m}^{3}$, respectively) were obtained when the plants irrigated by 50 and $100 \%$ irrigation levels and $21 / \mathrm{h}$ emitter discharge under surface trickle irrigation system.

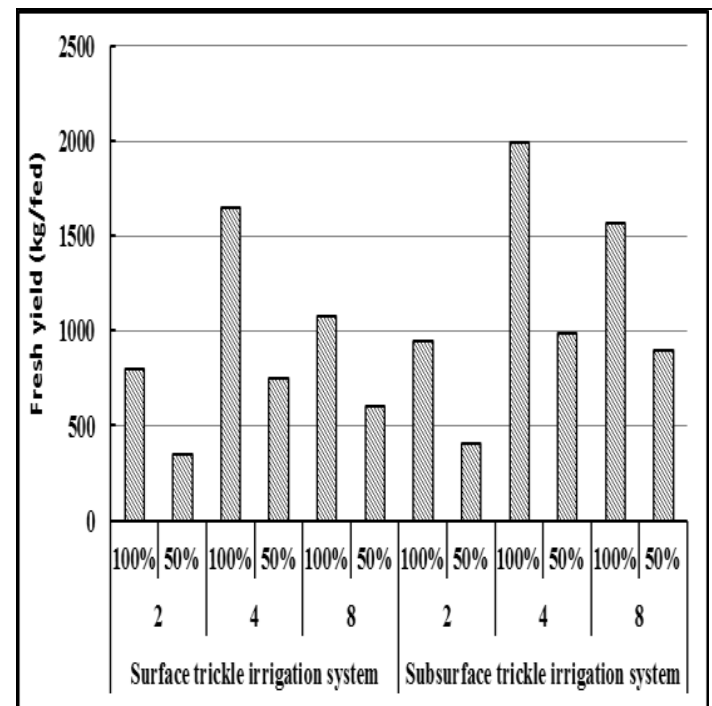

Figure (3) Fresh yield as affected by the different treatments.

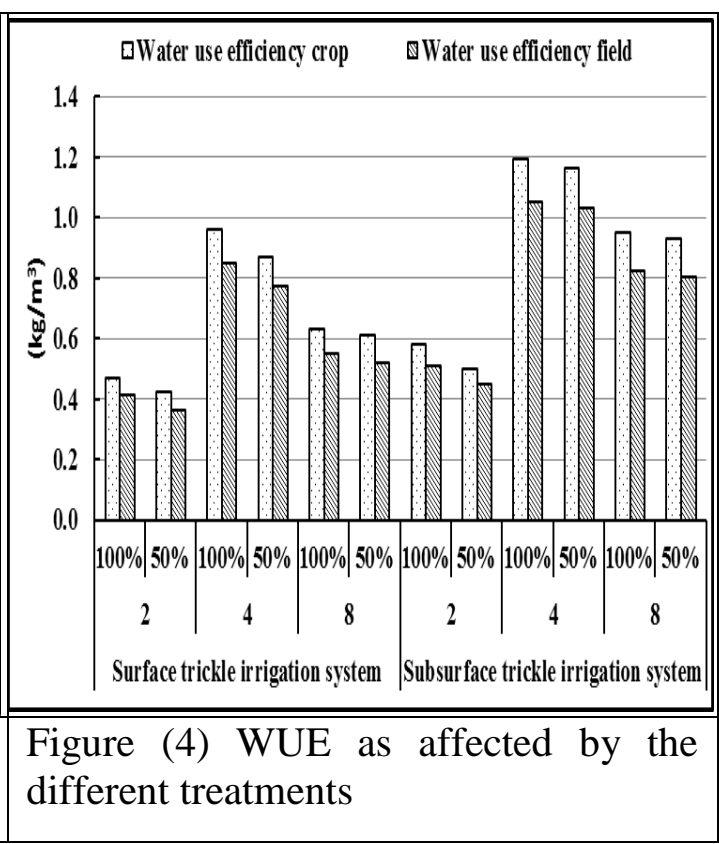


As for the results of the soil moisture pattern, they are presented on figures (5) and (6).The results indicated that the redistribution process was nearly completed 48 hours after irrigation in all studied treatments. However, it is clear that the moisture distribution pattern was greatly affected by the irrigation systems, the emitter discharges and the irrigation water levels. The main differences in the moisture content, at the end of respective irrigation, applied water for both three emitter discharges rates and two irrigation water levels, seem to be located away from the trickle line. The highest discharge produced greatest radius to depth ratio while the reverse was true for the lowest discharge one under the same irrigation water level and the same irrigation system. Subsurface trickle irrigation system treatments exhibited a moisture content that ranged between (17 to 22, 20 to 31 and 22 to 32) and (12 to 18, 16 to 22 and 18 to $26 \%$ ) by weight near the leaky pipe in the top $0-15$ and $15-30 \mathrm{~cm}$ layers at the 0 to $20 \mathrm{~cm}$ distances from the emitter for $2,4,81 / \mathrm{h}$ emitters discharges with 100 and 50\% irrigation water levels, respectively. Out of these layers it decreased gradually. The decrease was more pronounced in the deepest layer $(45-60) \mathrm{cm}$ and farest distance $30 \mathrm{~cm}$ from the emitters which revealed $(7,12$ and 14) and $(6,9$ and $10 \%)$ by weight in the same order. The lowest emitter discharge under both irrigation water levels had less moisture content approximately less than field capacity in the most of layers at the most distances from emitters, thus the available water in the depth of root proliferation at the first stage of plant growth may be insufficient to meet the plant demand at this period. Many plants respond to subsurface irrigation by root proliferation within a more or less cylindrical volume of soil immediately surrounding the trickle tubing (Abou El Azem et al.,2002). The surface trickle treatments exhibited a moisture content ranged from about (13 to 22, 20 to 30 and 26 to 33) and (13 to 18,15 to 24 and 16 to 28 ) \% by weight under the emitters in the top $0-15$ and $15-30 \mathrm{~cm}$ layers at the 0 to $20 \mathrm{~cm}$ distances from them for 2,4 , $81 / \mathrm{h}$ emitters discharges with 100 and $50 \%$ irrigation water levels, respectively. Out of these layers it decreased gradually. The decrease was more pronounced in the deepest layer $(45-60) \mathrm{cm}$ and first distance $30 \mathrm{~cm}$ from the emitters which revealed $(8,13$ and 15$)$ and $(6,10$ and 10) \% by weight in the same order. 



Misr J. Ag. Eng., October 2013 
Regarding the results of soluble salts distribution pattern, they are presented on figures (7) and (8). They revealed that the soil salinity (EC $\mathrm{dS} / \mathrm{m}$ ) at the end of the irrigation season was affected by the moisture distribution which in turn governed by the irrigation systems, the emitters discharges and irrigation water levels. The soil salinity under surface trickle irrigation system increased throughout the growing season in all the treatments under study at certain locations with relative differences according to the rate of discharge and irrigation water level. The irrigation with surface trickle system produced three salinity zones which they were an upper salinity zone near the soil surface with high salt concentration, a wide intermediate zone where salinity concentrations were low near the emitters at the soil surface and a lower zone where the salinity concentrations increased with the depth and the distance from the emitters. Concentration of salts at the end of the growing season under discharge $2 \mathrm{~L} / \mathrm{h}$ varied very little with time and was very close to the irrigation water salinity. The EC values ranged from about ( 0.88 to 1.95 , 0.71 to 1.74 and 0.65 to 1.43 ) and (1.14 to $2.17,0.98$ to 1.92 and 0.81 to 1.78) $\mathrm{dS} / \mathrm{m}$ at the radius of $20 \mathrm{~cm}$ for 2,4 and $81 / \mathrm{h}$ emitters discharges with 100 and $50 \%$ irrigation water levels, respectively. Out of this radius it increased gradually. The increase was more pronounced in the deepest layers (30-45) $\mathrm{cm}$ and first distance of $30 \mathrm{~cm}$ from the emitters at the soil surface which revealed $\{(2.80$ and 2.66), $(2.40$ and 2.17) and (2.17 and 1.87), respectively $\}$ and $\{(2.95$ and 2.83), (2.69 and 2.56) and (2.45 and 2.00 ), respectively $\} \mathrm{dS} / \mathrm{m}$ in the same order. Therefore, pea plants, grown under the emitters, had $4 \mathrm{~L} / \mathrm{h}$ discharge rate were in relatively less stressed (more or/and less moisture content and salt concentration) environment, than any other rates, indicated that relatively small or big changes in water movement bring about considerable changes in soil salinity. However, decreasing emitter discharge rate and irrigation water level resulted in higher average salinity profiles and led to a high concentration in the soil salinity at the end of the growing season. In addition, the increased both of them were allowed for water percolated below the root zone which helped in more leaching for salts. Same results were reported by Petersen (1996). 
The lowest emitter discharges and irrigation water levels developed the highest salt concentration in the root zone and near the soil surface. This might be due to shallow wetted depth, since water movement was directed horizontally rather than vertically. Capillary forces as well as the shallow wetted depth promote salt accumulation at the soil surface due to the salt build up by evaporation components. Concerning the subsurface trickle system resulted in higher salinity levels at the upper and lower soil layers than with the surface one and the salt concentration tended to increase around the root system for all the emitters discharges. The EC values ranged from about (1.01 to $1.77,0.81$ to 1.61 and 0.79 to 1.40 ) and (1.38 to $2.32,1.21$ to 2.00 and 1.06 to 1.81 ) dS/m at the radius of $20 \mathrm{~cm}$ for 2, 4, 81/h emitters discharges with 100 and 50\% irrigation water levels, respectively. Therefore pea plants could be grown for a considerable period without high stress under the emitters had $41 / \mathrm{h}$ discharge rate, because of the upper part of the root zone is relatively maintained at lower salinity level and the salinity stress might had some impact on root water uptake for both low and high discharges rates.

The higher salt concentrations with subsurface trickle irrigation can be expected because the dispersion flows of saline solution inside the wetted soil volume were may be due to capillarity force and bulk flow. Therefore, a progressive accumulation of the salts not used by the plant occurs in all the soil layers and especially in the upper portion of the soil.The salt distribution pattern in subsurface trickle irrigation system treatments under each studied emitter discharge and irrigation water level tended to concentrate in the upper layers where there were much less roots which grew markedly in the lower layers. While in the surface trickle irrigation system treatments the salts concentrations decreased from the top layers to the bottom of the wetted soil which the roots tended to occupy the whole wetted zone. Moreover, the salinity increasing of the upper layers in the subsurface trickle treatments more than in the surface one were mainly may be due to a great deal of salts which were directed to move upward by capillary forces. Generally, the subsurface trickle treatments resulted in relatively low vertical rang in salt concentration that showed a tendency to accumulate in the top layers while the reverse phenomenon was observed in surface one. 


water using class A pan.

$100 \%$ of calculated amounts of
irrigation water using class A pan.

Figure (8) Distribution of salts in the soil profile (EC dS/m) at the different distances from both sides of emitters and at different depths as affected by all the studied treatments under subsurface trickle irrigation system 


\section{CONCLUSIONS}

According to the previous results and discussions, it can be concluded that:

- The relationship between both emitter discharges and irrigation water with different rates or levels had a positive impact on pea fresh yield where the total fresh yield was increased by increasing both of them.

- The actual consumptive use is related directly to both emitter discharges and irrigation water rates or levels. The most probable explanation for this is that the higher the emitter discharge and the more the irrigation used or applied the more the chance for more luxuriant plants used the soil moisture which resulted in increasing the transpiration.

- Both crop and field water use efficiencies were increased significantly by increasing both emitters discharges and irrigation water rates or levels. This increase is mainly due to the correspondence increase in crop yield.

- The highest crop and field water use efficiencies values were obtained when the pea plants irrigated by $100 \%$ irrigation level and $41 / \mathrm{h}$ emitter discharge under both subsurface and surface trickle irrigation systems $\left(1.19,1.05,0.96\right.$ and $0.85 \mathrm{~kg} / \mathrm{m}^{3}$, respectively).

- The lowest values were $\left(0.42,0.36,0.47\right.$ and $0.41 \mathrm{~kg} / \mathrm{m}^{3}$, respectively). They were obtained when the plants irrigated by 50 and $100 \%$ by of calculated amounts using class A pan method irrigation levels and $2 \mathrm{~L} / \mathrm{h}$ emitter discharge under surface trickle irrigation systems.

- In general, total yield, water consumptive use and both crop and field water use efficiencies were increased for pea crop when irrigated by subsurface trickle irrigation system compared to surface irrigation with each emitter discharge and irrigation water level. This could be due to the good distribution of salt and water applied which should be sufficient to replace moisture and nutrient depleted from the root zone to avoid both water and nutrient stress on the growing plants.

\section{REFERENCES}

Abou El Azem, A. M.; T. M. Husien and A. A. Nassar (2002).

Subsurface trickle system management for vegetable production. Egypt. J. Appl. Sci.; 17 (12): 425- 448.

Ahou EL Azem. A.M. and A. T. Abdel Aal (2009). Interaction between water applied and nitrogen fertilizer on yield of tomato. Water 
Science, Scientific Journal of the National Water Research Center, Issue No. 45: 89-104.

Assouline, S. (2002). The effects of micro drip and congenital drip irrigation on water distribution and uptake. Soil Sci. Soc. Am. J., 66: 1630-1636.

Black, C. A. ( 1965). Methods of soil analysis . Amer. Soc. Of Agron. Inc. Madison, Wisconsin, U. S. A.

Doorenbos, J. and A. H. Kassam (1979). Yield response to water. FAO Irrigation and Drainage Paper No. 33, Rome.

Doorenbos, J. and W.O. Pruitt (1977). Crop water requirements. Irrigation and Drainage Paper No. 24 FAO, Rome, Italy.

El Berry, A. M. (1989). Design and utilization of subsurface drip irrigation system for fodder production in arid lands. Misr, J. of Agric. Eng. Egypt, 6 (2): 153-165.

El Berry, A. M.; E. Haffar and M. H. Ahmed (1990). Utilization of BiWall subsurface drip irrigation system for vegetable production under desert conditions. Misr, J. of Agric. Eng. Egypt, 7 (1): 17-23.

El Mansi, A. A.; H. M. E., Arisha; A. Bardisi and E. M. Nour (1999). Studies on some factors affecting growth and yield of pea under some soil conditions using drip irrigation system. 1- effect of sowing date and irrigation water quality. Zagazig, J. Agric. Res., 26, (5): 1385-1407.

Garcia, I. (1978). Soil water laboratory Manual. Dept. Agric. And Chemical Engineering. Colorado State Univ., Fort Collins, Colorado, U.S.A.

Israelsen, O. W. and V. E. Hansen, (1962). Irrigation principles and practices $3^{\text {rd }}$ Edit., John Willey and Sons Inc., New York.

Jensen, M.E. (1983). Design and operation of farm irrigation systems. Amr. Soc. Agric. Eng. Michigan, U.S.A.

Martinaz Hemandz, J. J.; Bar-Yosef and U. Kafakafi (1991). Effect of surface and subsurface drip fertilization on sweet corn rooting uptake, dry matter production and yield. Irrigation Sci., 12 (3): 153159. 
Shalhevet, J. (1994). Using water of marginal quality for crop production: major issues - review article. Agricultural Water Management 25: 233- 269.

Snedecor, G. W. and W.G. Cochran (1980). Statistical methods. $7^{\text {th }}$ Iowa Univ., Press, Amer., Iowa, U.S.A.

Vermeiren and Jobling (1980). Localized Irrigation, Irrigation \& Drainage Paper No. 36, FAO, Rome.

الملخص العربي

\section{تقييم تطبيق نظامى الرى بالتنقيط السطحى والتحت سطحى لزراعة البسلة فى الزي الأراضى الرملية}

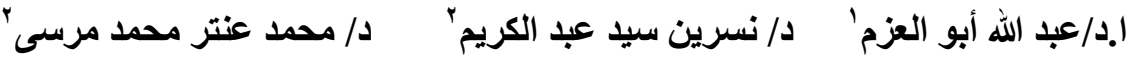

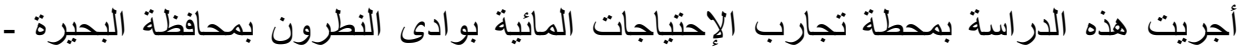

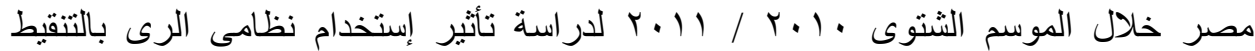

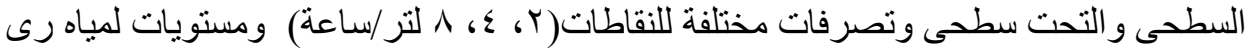

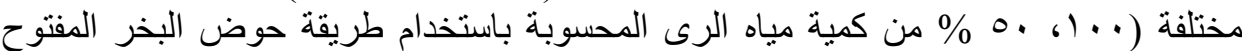

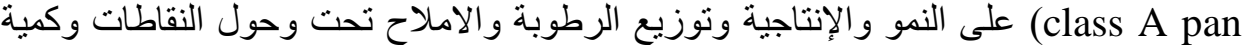



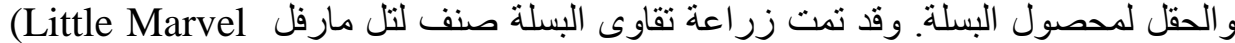
L.L.)

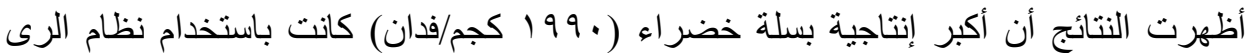

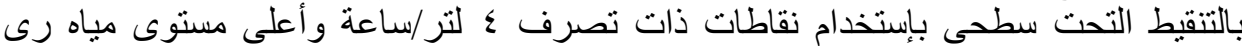

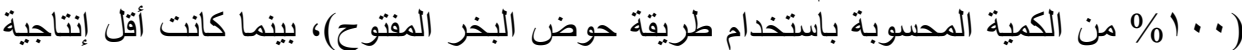

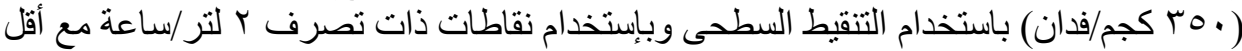

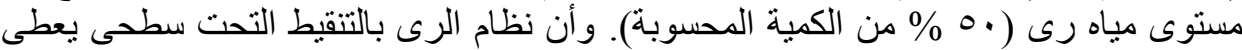

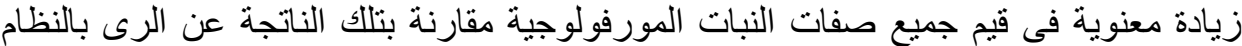
السطحى. زبادة معن.

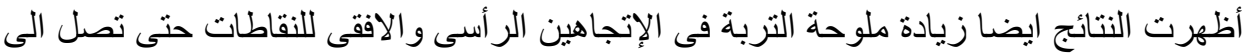

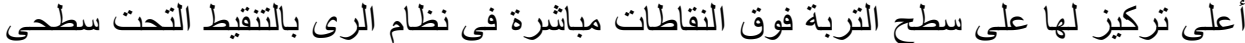

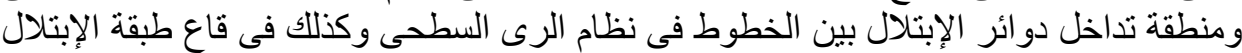

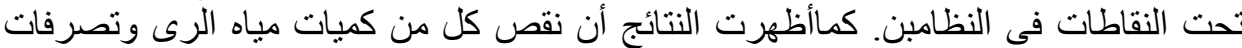

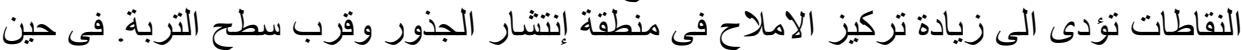

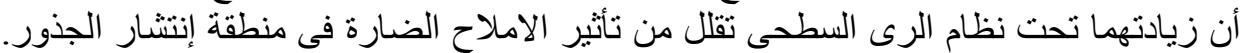

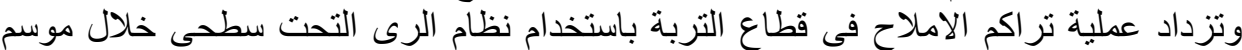
النمو وذلك فى الاجز اء العليا والسفلى من منطقة الإبنالال مقارنة بالنظام السطحى. بالني.

$$
\text { r باحثت ـ معهل بحوث ادارة المياه ـ المركز القومى القوى لبحوث المياه المياه. }
$$

